doubt that the cuticle of insects shows 'asymmetrical permeability', that is, moisture can pass more easily in one direction than in the other, across the cuticle. This is simply explained if the cuticle consists of two sides, one side having its permeability to water vapour decreased when in contact with a fairly high humidity, the other side being unaffected, or less affected. Such a complex membrane would pass water more easily from the less moisture-sensitive side than from the other side, because, when the higher humidity is on the side most affected by water, the permeability is decreased.

Cases of actual secretion of water into the body of an insect, from a bumidity less than that in equilibrium with the interior of the insect, are not uncommon with living insects ; one explanation which was suggested at the meeting, perhaps rather too crude to be correct, is that water is first condensed in capillaries so narrow that the meniscus on the top of the condensed column of water in the capillary is very sharply curved, so that condensation takes place below 100 per cent humidity; then the contents of the capillary tube are sucked into the insect's body from below. Very large suctions would have to be exerted.

Other subjects discussed included the behaviour of water in soils, textiles, coal and wood; also the determination of surface area by adsorption of gases, or the negative adsorption of inorganic ions in aqueous solution; and the estimation of pore size from the vapour pressure required for condensation, from the viscous resistance to flow through the porous material, or indirectly from the estimated internal surface of the solid.

The proceedings were pleasantly informal and friendly, as usual, despite the grievous loss the Society has suffered through the death of its honorary secretary, Mr. G. S. W. Marlow. Although the physico-chemical explanation of many of the phenomena which the biologists brought before the meeting remains very uncertain, and some seem to require 'biological' mechanisms much more complex than those found in non-living systems, the discussion was valuable in defining and clarifying some fundamental biological processes, as well as surveying the manner in which water interacts with several important industrial materials.

N. K. ADAM

\section{AN EXPERIMENT IN MARINE FISH CULTIVATION}

\section{By L. H. N. COOPER and G. A. STEVEN}

$M^{A}$ ANY stages of the food-cycle in the sea are 1 much better known to-day than a quarter of a century ago. None the less, the synthesis of the scattered pieces of knowledge into a coherent whole and the assessment of the weight to be given to each has scarcely begun. An experiment in marine fish cultivation such as that of Gross, Orr, Marshall and Raymont $^{1}$ in Loch Craiglin, Argyllshire, during 194244, which has attempted this is therefore of outstand. ing importance and is worthy of a considered and vigorous criticism. The experiment suffered from many shortcomings which this group of able workers are the first to admit. The aim was set very high and the time that could be devoted to the projectmainly week-ends-under the severe stress of war conditions was inadequate. The experiment failed in its primary objective of demonstrating that marine fish cultivation can be made to pay. In the series of papers embodying the results, one senses that this failure-a failure on the heroic scale-has infected the authors with so great a feeling of disappointment that in the end they have not dared to draw from their data even those conclusions that their results would seem to justify.

One of us $^{2}$ has already stated his view that encouragement of fish growth in arms of the open sea such as the North Sea or English Channel by addition of nutrients can never be a paying concern. Indeed, in not so many years there well may be a call for means of recovering nutrients, particularly phosphorus, from the sea. None the less, he feels that the Loch Craiglin experiment shows that in selected basins and arms of the sea a satisfactory return on money expended is a definite possibility.

For the purpose of the experiments, Loch Craiglin is as unsuitable as any basin well could be; but this very unsuitability has thrown into high relief some of the adverse factors with which the marine pisciculturalist will always have to contend. The waters of the Loch were nearly always very strongly stratified. This stability was due not only to heating of the surface layer in summer but also to the presence of a chronic seal of brackish water, the salinity of which varied between 8 and $28 \%$. Even under unfertilized conditions, ventilation of the water by exchange of oxygen and carbon dioxide with the atmosphere must have been restricted. The addition of nutrients encouraged the phytoplankton further to strip the surface of carbon dioxide, the $p H$ rising to more than 9. At the same time, at a depth of 3 metres in this very opaque stratified water, with Secchi disk readings averaging 2-3 metres, decomposition of the rain of organisms from above lowered the $p H$ to $7 \cdot 5$. The corresponding partial pressures of carbon dioxide calculated from Buch's tables ${ }^{3}$ would have been about 0.18 and $18 \times 10^{-4}$ atmospheres, a range of one hundredfold. Animals and plants that can tolerate such a range of conditions are few. Healthy development of a balanced plant and animal community in a fertilized basin can occur only if vertical mixing and ventilation are adequate for the increased task. The authors seem to regard this ill-ventilation as an act of God about which nothing can be done. In Loch Craiglin this is probably so; but, for future development, the engineering problem of turn-over and ventilation is possibly the most important of all. Not only would improved turn-over revivify the bottom water and fertilize the surface water with carbon dioxide, but also it would circulate the added nutrients and iron to the upper layers where plants could re-use them immediately.

The water in Loch Craiglin had always a transparency far less than that of the open sea, Secchi disk readings averaging 2-3 metres, compared with the 10-15 metres in the English Channel; and the extinction coefficient for green light ranged from 0.5 to 14 (coastal water $0 \cdot 2-0 \cdot 3$ ). This means that the range of depths well suited to active photosynthesis must have been measured in centimetres rather than metres. Much of the turbidity arose from biological activity within the Lochactivity that must be better understood if a way of dealing with it successfully is to be devised.

The problem of 'weeding' also arose in an acute form. When a field is infected with even such a persistent weed as charlock, a farmer has ways of dealing with it. If he does not, he will not succeed 
as a farmer for Iong. In Loch Craiglin, bottom-living plants such as Enteromorpha, Cladophora, Zostera and Ruppia took the first large share of the added nutrients. They were weeds and needed to be treated as such, although it is hard to see how this could have been attempted with any great hope of success.

Microflagellates were richer than normal; but no clear-cut dependence on single fertilizations, light or hydrographical factors could be detected. Their growth requirements and physiology are still too little understood.

On the bottom fauna the effect of fertilization was remarkable. By the summer of 1943, sampling and computation indicated that the population density of the bottom fauna in the whole Loch had increased by an average of about 750 per cent over the prefertilization value; this despite heavy feeding by the large number of introduced fishes. This high value declined, however, until, in the winter of 1944, it reached a fairly stable level about 300 per cent above the corresponding pre-fertilization winter density of 1942. This increased population density produced an increase of several hundred per cent in total dry organic weight. These increases applied not to one but to all the common species useful as food. For some unexplained reason the chief two invertebrate 'competitor' species, Anemonia and Ciona, suffered a diminution in numbers. This did not apply to gobies and sticklebacks, which multiplied and flourished to such an extent that in one day, in August, they are computed to have eaten no less than eighteen times as much food as the total population of 'economic' flatfishes.

Too much weight must not be attached to the actual figures; the important point is that they undoubtedly reveal a very large increase in the invertebrate bottom fauna of the Loch due to artificial fertilization. This probably explains, in part at least, the rather unexpected finding that flatfishes in Loch Craiglin continued to feed heavily and even to grow throughout the winter.

The growth-rates of the flatfishes were investigated by means of marking experiments. These were not very successful; the marks became entangled in bottom weed and eelgrass, or inflammation of the wound interfered with growth. There was evidence, however, that unmarked plaice made the equivalent of two years ordinary growth in one year. But most work had to be done with flounders, mainly unmarked. In one year many of these showed weight increases up to about eighteen times that of the normal increment for this species in average natural conditions.

These high growth increments in large numbers of fish were not maintained. In 1943 the flatfish population was as much as 1,000 per acre $(2,500$ per hectare), but during the year it was very largely wiped out by cormorants, herons and at least one otter. Nevertheless, in spite of failures such as this, these experiments have demonstrated most convincingly that by the application of fertilizers Loch Craiglin, in spite of its 'dirty' bottom and unfavourable hydrographical conditions, was rapidly converted into a feeding ground approaching the richest natural feeding ground known. Although the authors have hesitated to say so, it is reasonable to believe that, if certain salient features could be dealt with, such an enclosed loch might be made far richer in fish production than anything known in Nature. These are :

(1) Ventilation. The addition of fertilizers must exacerbate the unbalance of carbon dioxide and $p H$ that always develops in stratified water-and stratification is inevitable in summer or after heavy rainfall. Natural processes of vertical mixing need to be assisted. Here the engineer must be called in to devise some pumping or other mechanism for spread. ing bottom water on the surface in sufficient quantity to break down the stratification. Could wind power be used to keep the cost within economic limits?

(2) Fixed plants. These will thrive less well in deeper water, but are always likely to take toll of added nutrients. Their control provides a problem for research. In the absence of useful fish foodanimals that can be encouraged to eat them, an economic outlet must be sought for the seaweeds and eelgrass which would make it worth while to harvest them. This would also reduce their drain on the nutrients.

(3) Nature of the bottom and fishing gear. The muddy bottom of Loch Craiglin was in many ways an adverse factor. In particular, catching the fish was undesirably laborious and less successful than it need be. Either special catching gear, perhaps traps, is called for, or a sandy bottom is essential.

(4) Opacity of the water. As much as possible of the daylight penetrating into the water needs to be available for photosynthesis. In physical terms, high quantum efficiency of photosynthesis is required. Intensive production of living material in the sea leads everywhere to production of matter, possibly dead plant pigments, that seem to be resistant to breakdown. Their presence restricts absorption of light by the pigments associated with living plant cells. Much more needs to be learned about the chemical substances which bring about light absorp. tion and scattering in 'old water' and how they could be destroyed or turned to account.

Always when discussing marine fish cultivation, it is assumed that nutrients from terrestrial stocks are to be added to the sea. Yet the very great richness of Antarctic water in nutrient salts has come about by a process of concentration within the sea. Current systems, both horizontal and vertical, are such that the loss of nutrients caused by the rain of organic matter falling towards the bottom from the photic zone south of the Antaretic convergence is more than made up by upwelling of deeper and richer water. By contrast, in the Straits of Gibraltar, the relatively rich deep water flows out from the Mediterranean over the sill and is replaced by poorer Atlantic surface water. The net result of the exchange is an impoverishment in nutrients of this great Sea, and consequent poor fisheries. Cannot something be learned from these natural events that could be applied, for example, to a large tidal sea loch with a narrow deep entrance that could be easily dammed ? Let it have two sluices, one at the foot of the dam, opened to allow deep nutrient-rich water to enter on the rising tide, the other at tide level to allow surface water, stripped of nutrients, especially in summer, to escape on the falling tide. In time, a concentration of nutrients would build up (as in the Antarctic) higher than would ever be found in the adjacent open sea, and should open up great possibilities of successful fish farming. Under these conditions it would be worth while to remove unwanted fixed plants for use as field dressings.

The cost of building such a dam solely for purposes of an artificial fishery would no doubt prove prohibitive. Equally the construction of such dams to convert tidal energy into electric power has also been burked on the grounds of cost. There should be no 
loss of hydrostatic height involved in leading the water from the foot of the dam by way of a siphon through a turbine rather than from the incoming surface water, as would normally be done. The combination of simultaneous production of power and fish from the one investment might prove economic. This is another matter for consideration by engineers. In short, this unique experiment has provided such a mass of interesting and important facts as will stimulate academic research and practical endeavour in many parts of the world.

${ }^{1}$ Proc. Roy. Soc., Edinburgh, 63 (1947). An Experiment in Marine Fish Cultivation. No. 1 . Introduction. By Dr. F. Gross. 18 No. 2. Some Physical and Chemical Conditions in a Fertilized Sea-Loch (Loch Craiglin, Argyll) by Dr. A. P. Orr. 38 . No. 3 The Plankton of a Fertilized Loch. By Dr. S. M. Marshall. $2 s .2 d$. No. 4. The Bottom Fauna and the Food of Flatfishes in a Fertilized Sea-Loch (Loch Craiglin). By J. E. G. Raymont. $38.8 d$. No. 5. Fish Growth in a Fertilized Sea-Loch (Loch Craiglin). By Dr. F. Gross. 78. 8d. See also Nature, 153, 483 (1944); 158, 187 (1946).

${ }^{2}$ Cooper, L. H. N., J. Mar. Biol. Assoc., 27, 326 (1948).

${ }^{3}$ Buch, K., "Der Borsăuregehalt des Meerwassers und seine Bedeutung bei der Berechnung des Kohlensăuresystems im Meerwasser" Cons. perm. int. pour l'explor. de la mer, Rapp. et Proc.-verb., 85 71 (1933).

\section{O BITUARIES \\ Prof. Alexander Ogg}

For more than forty years Alexander Ogg, who died on February 23, had been by common consent the much-loved leader in his subject of physics in South Africa. A Scotsman by birth, he graduated in the University of Aberdeen under Prof. Niven and afterwards obtained his doctorate as an 1851 Exhibitioner under Nernst in Göttingen. His interest in thermodynamies arose during this period, and led to his well-known English translation of Planck's classic work on the subject. After this, he was for a time a lecturer at Aberdeen, which he left to become a master in the Royal Naval Engineering College, Devonport. In 1905 he migrated to South Africa to be the first occupant of the chair of physics and applied mathematics at Rhodes University College, Grahamstown. In so doing he became by no means the least illustrious of that band of Scottish teachers who have contributed so much to South Africa.

Ogg's new department at Rhodes College was housed in part of the old military barracks and bore the inscription "Sergeants' Mess" over its door. He set to work with great vigour and in the face of many difficulties to convert it with his own hands into a physics laboratory which would be not only the best in the country but also bear comparison with any overseas. He soon became acknowledged as an inspiring teacher and attracted to his honours courses the best brains of the College, whether they intended to become physicists or not. Year after year, in regular succession, the senior overseas scientific scholarship in the Union was won by one of Ogg's students, all of whom to-day occupy leading positions in the life of the country.

In 1917, after assisting Sir William Bragg for a time in England in military research, he moved to the University of the Witwatersrand, and in 1920 to that of Cape Town, where he remained until his retirement in 1936. When the University of Cape Town moved to Groote Schuur, he planned and fitted up the new de Beers Physical Laboratories, devoting his spare time to making them an outstanding monument to his wide experience and skill.

During his time in Cape Town, Ogg became interested in terrestrial magnetism, and when he re. tired from university life at the age of sixty-five he began a new one as director of the Government Magnetic Observatory, Hermanus, which again he planned and fitted up himself. Under his direction the Observatory has become well known internationally not only for its observations, which are con. sidered to be among the most accurate in the world, but also for Ogg's papers on $K$ indices of magnetic activity and on magnetic disturbances. He retired from the directorship in 1946, but maintained an active interest in the Observatory, as in all physical research in the Union, up to the time of his death.

The high standing of the subject of physics in South Africa is very largely due to Ogg's own high standards as a teacher and examiner. His students have become members of the staff of practically every university in the country, and his scholarly influence remains imprinted on both schools and universities. His time and energy, particularly in his early period, were so fully occupied with building up his departments that he had little available for research, though some valuable work on X-ray diffraction and crystal structure was done by him in Cape Town.

He was a fellow of the Royal Society of South Africa and its president for five years, a fellow of the Institute of Physics, the Physical Society, the Royal Microscopical Society and the Faraday Society. The University of Cape Town conferred on him the honorary degree of D.Sc. in 1936, and the University of Aberdeen that of LL.D. in the same year.

As a man, Ogg will be remembered for his kindliness and humour, his strict sense of justice and the great personal interest he took in his students. He always exercised an important influence on university affairs, an influence which was all the more effective because of his unassuming integrity.

\section{B. F. J. SChONLAND}

\section{Mr. Harry Price}

THRovar the death of Mr. Harry Price on March 29, psychical research has lost its most distinguished journalist and writer of popular descriptive accounts of adventures with the unknown. He was born in 1881, and from an early age was keenly interested in conjuring and magic, which soon led him to a desire to inquire more fully into the alleged physical phenomena of mediumship. An opportunity was given him in 1922 to visit Munich in order to be present at some sittings with the famous medium Willi Schneider, with whom the late Baron von Schrenck was at that time experimenting. From that period until the day of his death his interest in the problems of mediumship never weakened.

After the first properly equipped séance room had been built and opened by the Society for Psychical Research in February 1924, Mr. Price followed suit, and in December 1925 he opened what he called the National Laboratory of Psychical Research, with premises in the house of the London Spiritualist Alliance in South Kensington. From that date he pursued his inquiries and published his results with unremitting zeal and enthusiasm. His books and magazine articles were written in popular and colloquial style, and it was through them that many people became acquainted with psychical research who would otherwise have taken but little interest in the subject.

Mr. Price had a wide knowledge of his subject, and in course of time accumulated what is undoubtedly 